\author{
A.L. Stepura, O.I. Aksimentyeva, P.Yu. Demchenko
}

\title{
Features of the Structure and Physical-Chemical Properties of Poly-Ortho-Toluidine Doped with Toluenesulfonic Acid
}

\author{
Ivan Franko national university of Lviv, Kyryla I Mefodiia Str., 6, 79005, Lviv, Ukraine, \\ e-mail:aksimen@ukr.net, anastagie@gmail.com
}

\begin{abstract}
Features of crystal structure, electrical conductivity and thermal stability of poly-ortho-toluidine (PoTi) samples, obtained with method of oxidative polymerization in the environment of sulfuric and toluenesulfonic acids (TSA), were investigated. It was discovered that PoTi-TSA samples are characterized withhigh crystallinity. According to the physico-chemical analysis, doping samples with TSA causes increase of PoTi thermal stability, electrical conductivity and sensor sensitivity on the contrary to samples doped with sulfuric acid. Based on temperature dependence of specific resistance, were calculated the values of the conductivity activation energy, which are within the limits of $0.2-0.4 \mathrm{eV}$ depending on the type of dopant.
\end{abstract}

Key words: poly-ortho-toluidine, toluenesulfonic acid, structure, specific resistance, thermal stability.

Article acted received 23.01.2019; accepted for publication 15.03.2019.

\section{Introduction}

Among the family of conductive polymers significant interest for research have polyaminoarenes (PA), which are as objects in many studies, because of their low price, great stability, simplicity of synthesis and possibility of control doped and undoped state, using acid-base interaction [1-5]. It is known, that electrical conductivity of polyaminoarenes can be changed in wide range (from $10^{-8}$ to $10^{2} \mathrm{~S} / \mathrm{cm}$ ) due to so called "proton" doping [1]. During treatment PA with proton acids or during the process of PA synthesis, in the environment of this acids are forming highly conductive forms of polymers, which preferably are emeraldine salts of the corresponding acids. At the same time, the nature of the doping acid anion substantially affects not only on the conductivity, but on the structure, morphology, electrical conductivity and thermal stability of PA. That's why an important issue is to study the influence of the dopant nature on the structure and physical-chemical parameters of conductive polymers.

Along with widely investigated polyaniline, currently are actively studied its derivatives polyaminoarenes, in particular, poly-ortho-anisidine [2], poly-ortho-toluidine [3,4] and others [5]. Special interests have their physical-chemical properties such as optical absorption, electrical conductivity and sensory sensitivity [6]. Due to the presence of alkyl substitute of the aromatic ring, these conductive polymers have improved solubility in comparison with polyaniline, and due to the features of the polymer chain structure, new functional properties can be detected.

Poly-ortho-toluidine (PoTi) has an elementary link structure rather similar to polyaniline (Fig. 1), but the presence of the electron donor substituent, the methyl group, in the ortho position to the amino group, causes a number of interesting physical, electrochemical and electrochromic properties [7-10]. Thus, is reported the use of PoTi in diode structures [4] as an electrochromic material for organic displays $[9,10]$, as component of sensors for detecting gases [3,6] and for creation of composite ion exchange materials [6].

On the other hand, to control the functional properties of poly-ortho-toluidine, as well as other conductive polymers, allows the choice of a doping agent. Among the known acid dopants quite promising, but little investigated is toluenesulphonic acid (TSA). The plasticization effect of TSA in polymeric composites based on polyaniline is reported [11], but the effect of this dopant on the structure and properties of PoTi has not been fully established.

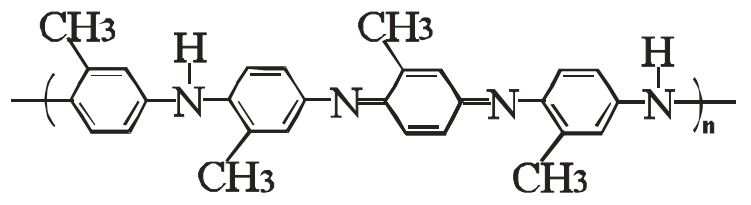

Fig. 1. Chemical structure of poly-ortho-toluidine. 


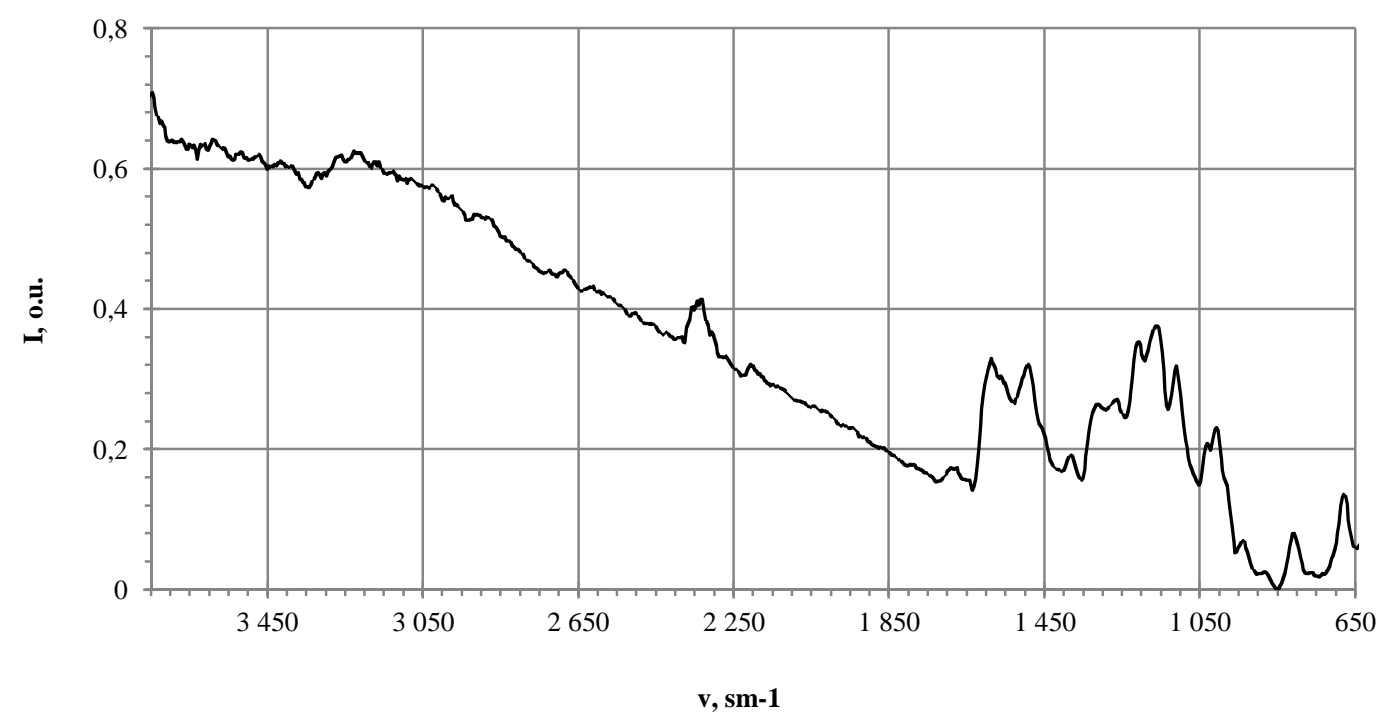

Fig. 2. IR spectrum of PoTi sample, doped with TSA.

The purpose of the work was to establish the features of the structure and properties of poly-ortho-toluidine doped with TSA.

\section{Materials and methods}

For synthesis of experimental samples as a monomer was used o-toluidine - $\left(\mathrm{H}_{3} \mathrm{C}-\mathrm{C}_{6} \mathrm{H}_{4}-\mathrm{NH}_{2}\right)$ - the mark "chemically pure"; obtained from the Sphere-Sim company; was distilled off in a vacuum before use. Relative molecular weight - $107.16 \mathrm{~g} / \mathrm{cm}^{3}$; $\rho=0.449 \mathrm{~g} / \mathrm{cm}^{3}$;as an oxidizer was used ammonium persulfate - $\left(\mathrm{NH}_{4}\right)_{2} \mathrm{~S}_{2} \mathrm{O}_{8}$ - the mark "pure for analysis" was purified with recrystallization from aqueous solutions. As doping agents were used ptoluenesulphonic acid $-\mathrm{CH}_{3} \mathrm{C}_{6} \mathrm{H}_{4} \mathrm{SO}_{3} \mathrm{H}$ - the mark "pure", and sulfuric acid - $\mathrm{H}_{2} \mathrm{SO}_{4}-$ "p"; $\rho^{20}=$ $1.835 \mathrm{~g} / \mathrm{cm}^{3}$. Used without additional cleaning.

The chemical synthesis of PoTi was carried out using a known method of oxidative polymerization of $0.1 \mathrm{M}$ o-toluidine solution under the action of an equimolar amount of ammonium persulfate oxidant [1, 7]. As a reaction medium, aqueous $0.1 \mathrm{M}$ solution of acids was used: TSA or sulfate acid. Polymerization was carried out at a temperature of $293 \mathrm{~K}$ under continuous stirring of the reaction mixture with a magnetic stirrer for 8 hours, after which it was left for 24 hours to complete the process. The resulting precipitate was filtered off and washed on a filter with distilled water to obtain a clear filtrate, and acetone to remove low molecular weight residues. The product was dried to constant weight under dynamic vacuum at $60^{\circ} \mathrm{C}$. As a result, the doped forms of PoTi-TSA or PoTi- $\mathrm{H}_{2} \mathrm{SO}_{4}$ were obtained in the form of emeraldinium salt, what was evidenced with the bright green color of the samples. To obtain an undoped polymer form, the obtained powders were washed with $5 \%$ ammonia solution to neutral reaction and dried in vacuum. It was received the non-conductive form of PoTi in the form of emeraldine base.

The molecular structure of the obtained samples was confirmed by the IR spectroscopy method using the spectrometer "Specord M-80" in the range of wave numbers $400-4000 \mathrm{~cm}^{-1}$. Samples for spectroscopy were prepared in the form of tablets compressed with $\mathrm{KBr}$ after careful rubbing in an agate mortar.

The phase composition of the samples and the crystalline structure of the poly-ortho-toluidine were investigated by X-ray analysis, using X-ray diffractometry of polycrystals with diffractometer STOE

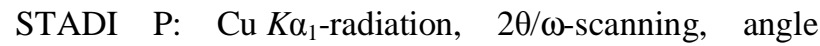
interval $4,000 \leq 2 \theta \leq 109,5852 \theta$ in increments of 0.015 ${ }^{\circ} 2 \theta$, scan time in step $300 \mathrm{~s}$. Measurements were carried out in the inter-faculty scientific-educational laboratory of X-ray diffraction analysis of IFNUL.

The thermal behavior of the samples was studied on the derivatograph "Q-1500D" of the Paulik-Paulik-Erdey system. Measurements were carried out in an atmosphere of air using corundum crucibles. The studies were carried out in the temperature range $273-1073 \mathrm{~K}$, with a heating rate of $10 \mathrm{~K} / \mathrm{min}$, using as the standard $\mathrm{Al}_{2} \mathrm{O}_{3}$. Using $\mathrm{TG}$ curve, it was determined the relative loss of sample mass at a fixed temperature. The relative mean square error did not exceed $5 \%$.

The electrical resistance was fixed using an automatic pulse ommeter-voltmeter B7-35, with a measuring range of $10-10^{9} \mathrm{Om}$. Specific resistance was calculated based on the formula: $R=(\rho \times 1) / S$, where $S$ is the cross-sectional area of the cylindrical specimen, 1 is height, $\mathrm{R}$ is the measured resistance, $\rho$ is the resistivity. Specific conductivity $(\sigma)$ was determined as a value reversed to a specific resistance. The relative error of the determination of $\sigma$ for a series of parallel measurements did not exceed $5 \%$.

\section{Results and discussion}

To study the molecular and crystalline structure of poly-ortho-toluidine doped with sulfuric and toluenesulphonic acids as well as non-doped PoTi form, a complex of physical-chemical methods was used: IR, 


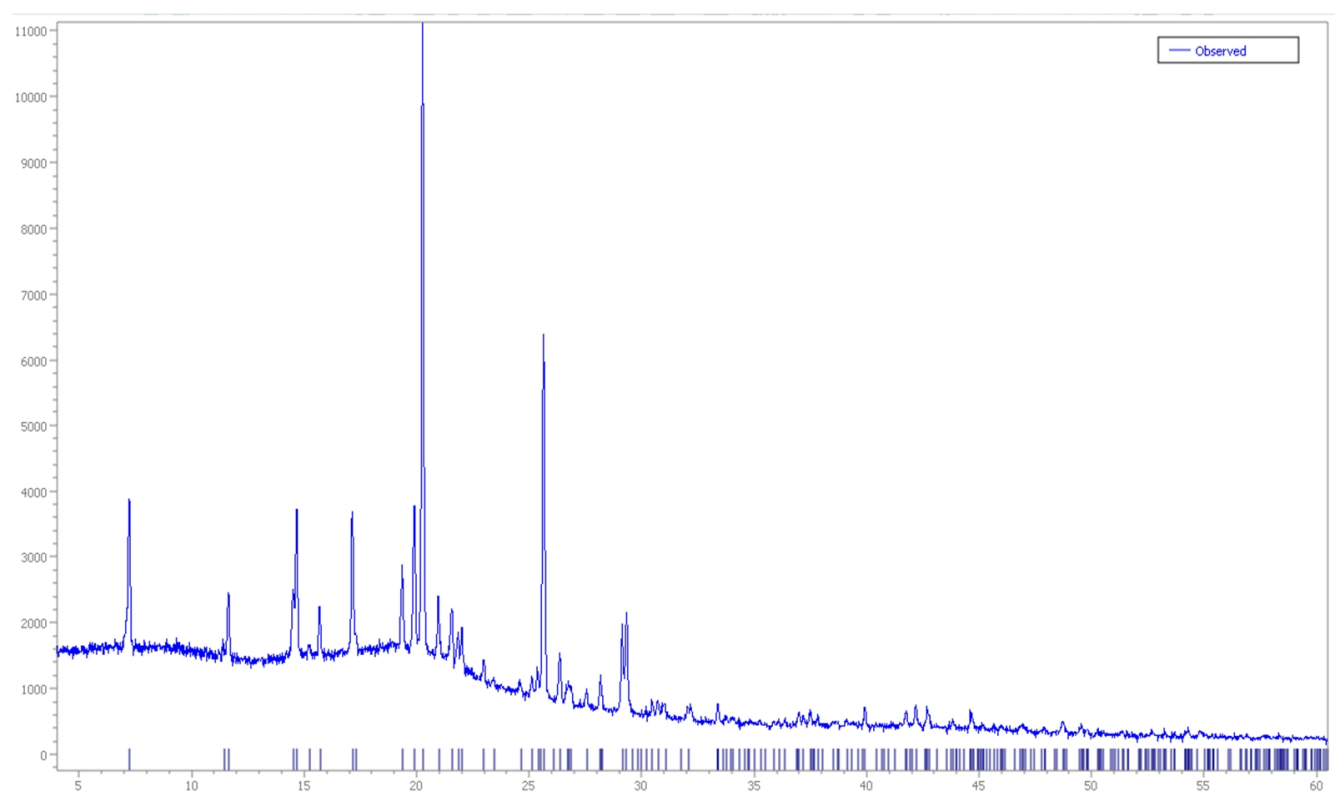

Fig. 3. X-ray diffractogram of PoTi sample, doped with TSA.

$\mathrm{X}$-ray diffraction, thermo-gravimetric analysis.

Figure 2 shows the IR spectrum of the PoTi -TSA. As can be seen from the graph, the spectrum is characterized by the presence of absorption bands characteristic for most polyaminoarenes [3, 12].

IR spectrum of doped polymer (PoTi-TSA) is characterized with a presence of the band at $3300 \mathrm{~cm}^{-1}$, bound to the hydrogen bond $(\mathrm{N}-\mathrm{H})$, and the band at $2910 \mathrm{~cm}^{-1}$, which can be attributed to stretching vibrations $\left(-\mathrm{CH}_{3}\right)$ of aliphatic bond. Two lines that appear at $1590 \mathrm{~cm}^{-1}$ and1480 $\mathrm{cm}^{-1}$, may belong to the stretching vibrations of the quinoid and the benzene rings, respectively. Bands at $1375 \mathrm{~cm}^{-1}$ are due to the symmetric deformation of the methyl group. Bands at $1320 \mathrm{~cm}^{-1}, 1210 \mathrm{~cm}^{-1}$ can be assigned to the vibration mode of $\mathrm{C}-\mathrm{N}$. Taking into account that absorption at $1150 \mathrm{~cm}^{-1}, 1110 \mathrm{~cm}^{-1}$, and $1105 \mathrm{~cm}^{-1}$ ischaracteristic for $\mathrm{C}-\mathrm{H}$, three bands that appear at $810 \mathrm{~cm}^{-1}, 880 \mathrm{~cm}^{-1}$ and $940 \mathrm{~cm}^{-1}$, were attributed to the out-planar $(\mathrm{C}-\mathrm{H})$ vibration of quinoid rings. The presence of bands at $1590 \mathrm{~cm}^{-1}$ and $1480 \mathrm{~cm}^{-1}$ clearly shows that the polymer consists of amino-imine chains. The spectrum has reduced intensity of hydrogen binding (-NH-group) at $3300 \mathrm{~cm}^{-1}$, due to formation of salt $\left(-\mathrm{N}^{+} \mathrm{H}_{2} \mathrm{CH}_{3} \mathrm{C}_{6} \mathrm{H}_{4} \mathrm{SO}_{3}\right)$.

It is known that conjugated polyaminoarenes are characterized with an amorphous-crystalline structure and represent itself an amorphous matrix with impregnated "domains" of the crystalline phase. The content of this phase or the level of crystallinity of PA substantially depends on the type of dopant and the degree of polymer doping [2].

Structural studies of non-alloyed PoTi and doped with sulfuric acid showed the presence of amorphous halo and several diffusion peaks, which indicate the existence of crystalline inclusions, which crystallinity degree is low [2]. It has been found that for PoTi samples, which are in an undoped state, the near order in the organization of the structure of matter and the corresponding amorphous structure prevails. When doping with sulfuric acid, an increase in diffuse maxima at $2 \theta=5.932^{\circ}$, which corresponds to the interplanar distance $\mathrm{d}=14.887 \AA$, is observed. This indicates the formation of a certain fraction of the crystalline phase with a low degree of crystallinity, but the dominant is the amorphous component.

When doping poly-ortho-toluidine with organic acid TSA undergoing radical changes in the matter structure organization of the polymer. According to the obtained diffractograms (Figure 3), for a PoTi-TSA sample, the long-range order and, accordingly, high degree of the phase crystallinity is dominant, while the content of the amorphous component is small, which is in good agreement with the results obtained in [3].

Analytical indexing of the obtained diffractogram showed that poly- $O$-toluidine doped with TSA crystallizes in a monoclinic syngony with parameters of the elementary cell $a=12.717$ (7), $b=6.938$ (4), $c=$ 8.069 (5) $\AA, \beta=106.71$ (1) ${ }^{\circ}$, the volume of the elementary cell $V=681.81 \AA^{3}$, and the possible spatial groups $-P 2_{1}, P 2_{1} / m$.

It should be noted that the crystalline structure of $\mathrm{p}$ toluenesulfonic acid monohydrate, as defined in [12], is also characterized with a monoclinicsyngony, the spatial group $P 2{ }_{1} / c$ and the parameters of the elementary cell $a=5.881, b=7.431, c=20.085 \AA, \beta=97.95^{\circ}, V=$ $868.49 \AA^{3}$.

It is likely, that in the process of doping PoTi with toluenesulphonic acid, the amino group of PA in the ortho-position acts as cation of the complex polymeric salt PoTi-TSA, where the anions are the acid residues of p-toluene sulphonic acid. The spatial and geometric similarity of the PoTi and TSA fragments causes formation of an ordered and more compact structure of the doped polymer. In this case, the fragments of the polymeric chain may enter into different elemental cells, what is proved for other conductive polymers [1].

Formation of the ordered crystalline structure of PoTi-TSA determines the features of the physical- 


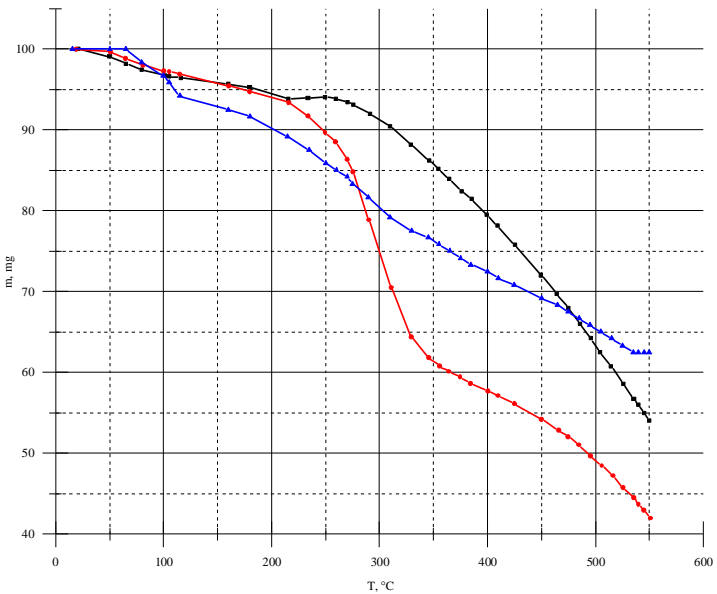

a)

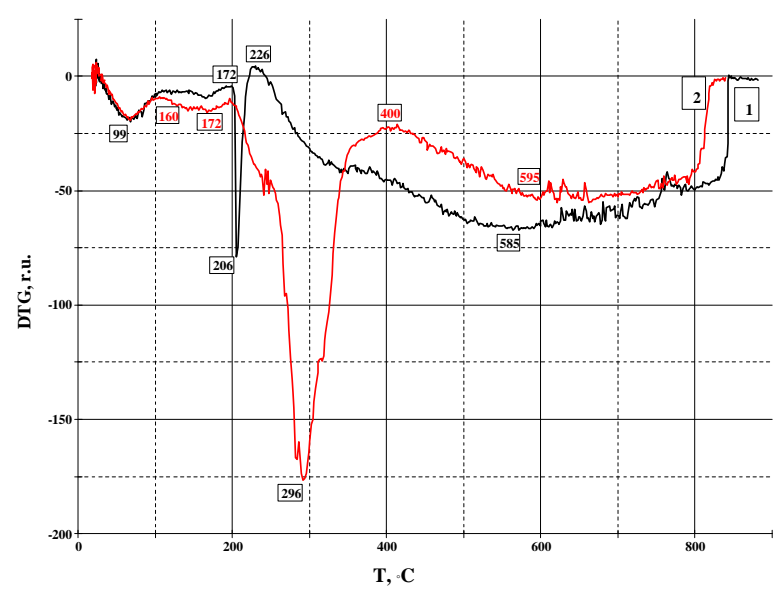

b)

Fig. 4. a) Thermogravimetric curves of undoped PoTi samples (2), PoTi doped with TSA (1) and PoTi doped with $\mathrm{H}_{2} \mathrm{SO}_{4}(3)$; b) Differential thermogravimetric curves (DTG) of decomposition of undoped PoTi samples (1)and PoTi doped with TSA (2)

Table 1

Values of weight loss of PoTi samples depending on temperature

\begin{tabular}{|c|c|c|c|c|c|c|c|c|}
\hline \multicolumn{3}{|c|}{ PoTi(undoped) } & \multicolumn{3}{c|}{ PoTi-TSA } & \multicolumn{3}{c|}{ PoTi-SO $_{4}$} \\
\hline $\mathrm{T},{ }^{\circ} \mathrm{C}$ & $\Delta \mathrm{m}, \mathrm{mg}$ & $\mathrm{m}, \mathrm{mg}$ & $\mathrm{T},{ }^{\circ} \mathrm{C}$ & $\Delta \mathrm{m}, \mathrm{mg}$ & $\mathrm{m}, \mathrm{mg}$ & $\mathrm{T},{ }^{\circ} \mathrm{C}$ & $\Delta \mathrm{m}, \mathrm{mg}$ & $\mathrm{m}, \mathrm{mg}$ \\
\hline 80 & 2.58 & 97.42 & 81 & 1.98 & 98.02 & 80 & 1.66 & 98.33 \\
\hline 101 & 3.29 & 96.71 & 100 & 2.73 & 97.57 & 100 & 3.33 & 96.66 \\
\hline 150.6 & 4.13 & 95.87 & 150.6 & 4.26 & 95.74 & 160 & 7.5 & 92.5 \\
\hline 200 & 4.98 & 95.02 & 200 & 5.98 & 94.02 & 215 & 10.83 & 89.16 \\
\hline 250 & 5.93 & 94.07 & 250 & 10.31 & 89.69 & 250 & 14.16 & 85.83 \\
\hline 300 & 8.65 & 91.35 & 301 & 26.09 & 73.91 & 300 & 19.58 & 80.41 \\
\hline 350 & 14.17 & 85.83 & 351 & 38.73 & 61.27 & 350 & 23.75 & 76.25 \\
\hline 400 & 20.51 & 79.49 & 401 & 42.32 & 57.68 & 400 & 27.5 & 72.5 \\
\hline 450 & 27.97 & 72.03 & 450 & 45.77 & 54.23 & 450 & 30.83 & 69.16 \\
\hline 500 & 36.57 & 63.43 & 501 & 50.95 & 49.05 & 500 & 35.83 & 64.16 \\
\hline
\end{tabular}

chemical properties of this material, such as thermal stability, specific electrical conductivity, sensory sensitivity, etc.

Thermogravimetric curves indicate that the investigated polymer, both in the doped with TSA and in the undoped forms, is quite stable. A small mass loss associated with the removal of moisture $(2-2.5 \%)$ is observed in the range of temperatures $80-100^{\circ} \mathrm{C}$ (Fig. 4 , a). With an increase in temperature to $150^{\circ} \mathrm{C}$ removes adsorption (bound) moisture. These processes correspond to small extremum on the DTG curve (Fig. 4, b).

The most significant mass loss, depending on the sample composition, begins when the temperature reaches $200^{\circ} \mathrm{C}$ and more (Table 1). In this case, the thermal behavior of the doped and undoped sample significantly differs. In the undoped state mass loss is around $5 \%$, whereas for the doped samples $-6 \%$ (PoTiTSA) and $11 \%$ (PoTi-SO ${ }_{4}$ ) possibly due to start of dopant loss.

As the temperature rises in the region from 250 to $350^{\circ} \mathrm{C}$ for PoTi-TSA sample, a sharp bend of the TG curve is observed, which corresponds to an intense extremum on the DTG curve with a maximum at $\mathrm{T}=$ $296^{\circ} \mathrm{C}$ (Fig. 4, b).

Analyzing these data and taking into account sources [13-15], it can be argued that in the range of 250$350^{\circ} \mathrm{Ctakes}$ place undoping process, associated with the removal of the doping admixture. In case of sulfatedoped samples the TG curve looks more slope, but there can be determined a row of a few characteristic meanings, which correspond to desorption of sulfuric acid: $195^{\circ} \mathrm{C}$ - start of dopant removing and $267^{\circ} \mathrm{C}-$ maximal rate of sulfuric acid removal. For anon-alloyed sample, such a plot points do not appear. Thermal decomposition occurs at a constant rate up to a value of $\mathrm{T}=850^{\circ} \mathrm{C}$.

The presence of spatial dopant with a mobile proton of sulfonic group enhances the physical-chemical properties of a polymer PoTi-TSA, which manifests itself in higher electrical conductivity and thermal stability compared with sulfate-doped PoTi. As can be seen from Table 2, the specific resistance of PoTi-TSA at room 
Table 2

Parameters of conductivity of aciddoped PoTi samples

\begin{tabular}{|c|c|c|c|c|c|}
\hline Sample name & $\begin{array}{c}\rho^{293}, \\
\mathrm{Om} \cdot \mathrm{m}\end{array}$ & $\sigma^{293}, \mathrm{~S} / \mathrm{m}$ & $\rho_{0}, \mathrm{Om} \cdot \mathrm{m}$ & $E_{\mathrm{a}}, \mathrm{eV}$ & $\rho^{293}{ }_{\mathrm{NH} 3} / \rho^{293}$ \\
\hline PoTi-TSA & 19.2 & $5.2 \cdot 10^{-2}$ & $1.8 \cdot 10^{-2}$ & $0.206 \pm 0.005$ & - \\
\hline PoTi-SO $_{4}$ & 4398.4 & $2.27 \cdot 10^{-4}$ & $6.6 \cdot 10^{-4}$ & $0.376 \pm 0.005$ & - \\
\hline PoTi-TSA+NH $_{3}$ & 9020.6 & $1.110^{-4}$ & $1.16 \cdot 10^{-5}$ & $0.708 \pm 0.005$ & 470 \\
\hline PoTi-SO $_{4}+\mathrm{NH}_{3}$ & $1 \cdot 10^{6}$ & $1 \cdot 10^{-6}$ & - & $0.564 \pm 0.005$ & 230 \\
\hline
\end{tabular}

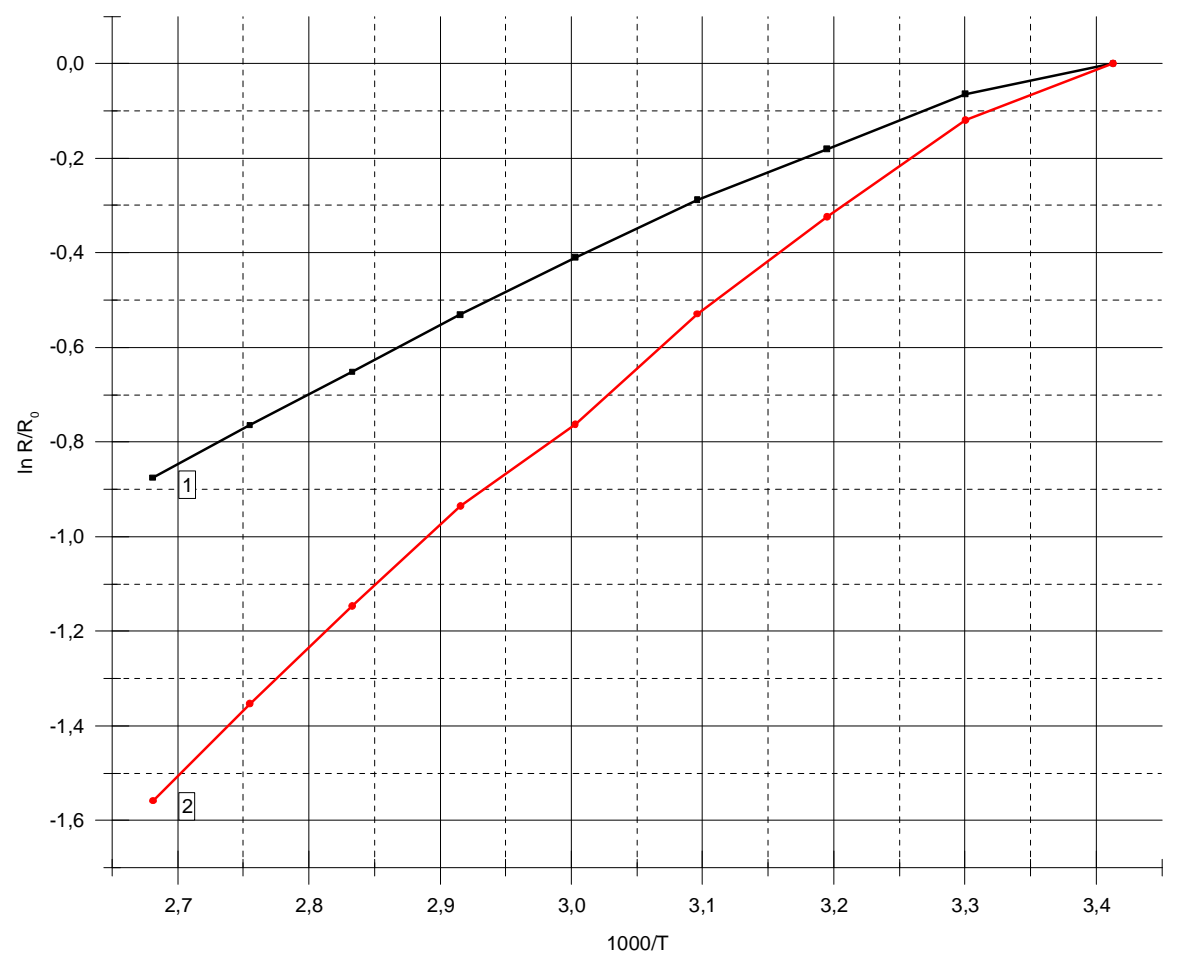

Fig. 5. Logarithmic dependence of resistance on inverse temperature for sample PoTi-TSA (1) and PoTi-SO 4 (2).

temperature is almost 200 times lower than that of $\mathrm{PoTi}_{-} \mathrm{SO}_{4}$.

According to the studies, it was found that with increasing temperature there is a decrease in the resistance of the investigated samples in the temperature range $293-373 \mathrm{~K}$. According to the exponential law $\rho=\rho_{0} \cdot \exp \left(E_{a} / 2 k T\right)$, where $E_{\mathrm{a}}$ is the energy of the activation of the charge transfer, $\rho_{0}$ is the resistance; $\mathrm{k}$ is Boltzmann constant, $\mathrm{T}$ - temperature.

The representation of the obtained data in the coordinates of the Arrhenius equation $\ln \left(R / R_{0}\right)=f(1 / T)$ showed that this temperature dependence is described by a straight line (Fig.5, a, b), which gives the possibility to calculate activation energy of conductivity for the investigated polymers [16].

As can be seen from the presented data, the activation energy of the charge transfer for PoTi doped with TSA is $0.206 \mathrm{eV}$, whereas for the sulfate-doped sample this value is $0.376 \mathrm{eV}$. By comparing the conductivity parameters, it can be concluded that doping
PoTi with toluenesulphonic acid provides rather high values of conductivity, in comparison with other acids, due, presumably, to the formation of an ordered structure under the influence of TSA.

It was found that under the action of gas (ammonia) there is a significant change in the resistivity, the value of $\mathrm{E}_{\mathrm{a}}$ and the constant $\rho_{0}$ of researched samples. Under the action of ammonia vapors, the value of resistivity varies from 19.2 to $9020.6 \mathrm{Om} \cdot \mathrm{m}$, i.e. 470 times, which indicates a high sensitivity of PoTi-TSA to the action of ammonia. For sulfate-doped PoTi, the growth of resistance occur almost twice less, and it means that the sensitivity, defined as the ratio of resistance after and before the action of gas, is 230 times. At the same time, the activation energy for PoTi-TSA increases almost 3.5 times in the case of ammonia action and for $\mathrm{PoTi}_{-} \mathrm{SO}_{4}$ it increases by 1.5 times (Table 2 ). 


\section{Conclusions}

Based on studies of the structure and properties of PoTi doped with acids, it has been established that the use of toluenesulphonic acid as a dopant causes a significant change in the crystalline structure of the polymer, which leads to an increase in thermal stability and an improvement in the conductivity of this material, compared with the sulfate-alloyed PoTi sample [17]. All this implies the promising use of PoTi-TSA in organic electronics devices, in particular resistive gas sensors.

Stepura A.L. - Master of Chemistry, engineer-researcher of the Department of Physical and Colloidal Chemistry; Aksimentyeva O.I. - Professor, Doctor of Chemical Sciences, Chief Scientist of the Department of Physical and Colloidal Chemistry;

Demchenko P.Yu. - Candidate of Chemical Sciences, Senior Researcher, Senior Researcher, Department of Inorganic Chemistry.

[1] A. MacDiarmid, Curr. Appl. Phys. 1, 269 (2001).

[2] O.V. Reshetnyak, G.E. Zaikov(Eds.) Computational and Experimental Analysis of Functional Materials (O.I. Aksimentyeva, O.I. Konopelnyk, D.O. Poliovyi.Chapter 3. Electrooptic phenomena in conjugated polymeric systems based on polyaniline and its derivatives), (Toronto, Apple Academic Press, 2017).

[3] A.A. Khan, S. Shaheen, Analytical Methods 7, (2015).

[4] A. Elmansouri, A. Outzourhit, A. Oueriagli, et al., Active and Passive Electronic Components, (2007).

[5] A.J. Heeger, Synth. Metals 123, (2002).

[6] A. Stepura, Yu. Horbenko, O. Aksimentyeva et al., Visnyk of the Lviv University, Series Chemistry, 58, (2017).

[7] M. Wan, Y. Jiping,Synthetic Metals 73, 201 (1995).

[8] K.M. Molapo, P.M. Ndangili, R.F. Ajayi et al., Int. J. Electrochem. Sci., 7, 11859 (2012).

[9] O.I. Aksimentyeva, O.I. Konopelnyk, M.Ya. Grytsiv et al., Functional Materials 11(2), 300 (2004).

[10] J. Wang, X.W. Sun, Z. Jiao,Materials 3, 5029 (2010).

[11] E.A. Ly`senkov, S.V. Lobkov, Yu.P. Gomza ta in., Polimernyj zhurnal 33(4), 322 (2011).

[12] S.K. Arora, M. Sundaralingam Acta Cryst. 27, 1293 (1971).

[13] L. Abella, S.J. Pomfreta, P.N. Adamsa et al., Synth. Met., 84(1-3), 127 (1997).

[14] V.G. Kulkarni, L.D. Kampbell, W.R. Mathew, Synth. Met. 30, 321(1989).

[15] H.F. Hussein, K.M. Ziadan and K.I. Ajeel, Basrah Journal of Science (A), 29(1), 92 (2011).

[16] S.M. Ahmed and M.I. Abd-Elrhaman, Journal of Thermal Analysis and Calorimetry 91(1), 195 (2008).

[17] O. Melad and M. Jarur,Chemistry \& Chemical Technology 10 (1), (2016).

\author{
А.Л. Степура, О.І. Аксіментьєва, П.Ю. Демченко
}

\title{
Особливості структури та фізико-хімічних властивостей поліортотолуїдину легованого толуенсульфокислотою
}

\author{
Львівський національний університет імені Івана Франка, вул. Кирила і Мефодія, 6, 79005, Львів, Україна, \\ e-mail: aksimen@ukr.net, anastagie@gmail.com
}

Досліджено особливості кристалічної структури, електропровідності і термічної стабільності поліортотолуїдину (ПоТі), отриманого методом окисної полімеризації в середовищі сульфатної та толуенсульфокислоти (ТСК). Встановлено, що для зразків ПоТі-ТСК характерна висока кристалічність. За даними фізико-хімічних досліджень, легування зразків толуенсульфокислотою спричиняє збільшення термічної стабільності, електропровідності і сенсорної чутливості ПоТі в порівнянні з сульфатнолегованими зразками. На основі температурної залежності питомого опору розраховані значення енергії активації провідності, які лежать в межах 0,2 - 0,4 еВ в залежності від типу допанта.

Ключові слова: поліортотолуїдин, толуенсульфокислота, структура, питомий опір, термічна стабільність. 